\title{
Doing the dirty work: progress in the search for a reliable protocol for cardiomyogenesis
}

\author{
Jennifer K Redig ${ }^{1}$ and Eric Adler*
}

\begin{abstract}
Cardiomyocytes generated from pluripotent stem cells have the potential to facilitate our understanding of cardiac diseases and help in their treatment. However, realizing the full potential of this technology is limited by the field's inability to efficiently and reliably differentiate pluripotent stem cells into cardiomyocytes. But now, due to a massive undertaking by Burridge and colleagues in a recent issue of PLOS One, we are one step closer to the reliable creation of cardiomyocytes. By systematically addressing 45 different variables, Burridge and colleagues were able to develop a protocol that consistently produced cardiomyocytes independent of the cell source. However, work still needs to be done to increase the efficiency and definitively determine the maturity of the myocytes generated through such a protocol.
\end{abstract}

Pluripotent stem (PS) cells may be a useful tool for cardiovascular disease in three principal ways. First, they can help elucidate mechanisms underlying cardiac development. For example, embryonic stem cells have been used to define distinguishing features of cardiovascular progenitor cells [1]. Second, they can be used to model cardiac diseases, as demonstrated recently when induced PS (iPS) cells were used to create in vitro models of hypertrophic cardiomyopathy and long-QT syndrome $[2,3]$. Third, they have potential as a therapeutic modality, as some studies suggest that transplanting stem-cellderived cardiomyocytes can ameliorate heart failure $[4,5]$.

There are numerous PS cell culture protocols for cardiomyogensis. The most basic involves culturing the stem cells in serum for extended periods of time followed

*Correspondence: adlereric@me.com

2Department of Medicine and Cardiology, University of California, San Diego, San Diego, CA 92037, USA

Full list of author information is available at the end of the article by dissection of beating cells and expansion [6]. The appeal of this protocol is its simplicity and reproducibility. But these advantages are tempered by this protocol's inherent inefficiency, which is as little as $0.5 \%$ [7], and the systematic exclusion of cardiomyocytes that are not spontaneously beating.

More complex protocols involve the exposure of PS cells to a sequential variety of cytokines known to induce mesoderm formation and, subsequently, cardiac differentiation. Using these protocols the efficiency can approach $80 \%$ [8]. However, due to interline variability, cytokine regimens must often be optimized, which can be cost and time prohibitive, especially when working with iPS cells, which can demonstrate intrapatient variability. Other protocols can include treatment of culture surfaces [9], electrical or mechanical stimulus to coerce pluripotent cells to differentiation into cardiomyocytes, and genetic or drug selection systems to isolate cardiomyocytes [10]. However, all of these methods are limited. Genetic manipulation restricts downstream applications, particularly therapeutic ones. And the time required to serially transfect multiple iPS cell lines, first with reprogramming factors and then with cardiac selection vectors, can be cumbersome. In summary, current techniques suffer from being inefficient, expensive or overly tedious.

To further complicate matters, determining the degree of cardiac enrichment remains a challenge. Methods that tally the percentage of beating-cell clusters are too restrictive, as they exclude cardiomyocytes that do not spontaneously beat, while other methods that tally the percentage of cells expressing cardiac-specific proteins, such as troponin T, may be too permissive. Moreover, other more accurate methods, such as patch clamping, are too tedious to perform routinely on large populations of cells. Without a reliable and universal method to determine cardiomyocyte identity, comparing the efficiency of various cardiomyogenesis protocols remains difficult.

In a recent issue of PLOS One, Burridge and colleagues [11] attempted to address some of these problems by analyzing and systematically comparing 45 different variables for their ability to influence cardiomyogenesis. Using this information they then derived a protocol that combines standard culture techniques with more current 
techniques to efficiently and consistently generate cardiomyocytes regardless of the cell line used. Reportedly, this optimized system generated anywhere from 64 to $89 \%$ cardiomyocytes, as assessed by intracellular fluorescenceactivated cell sorting (FACS) staining of cardiac troponin t. Additionally, the differentiated cells physiologically and ultrastructurally resemble cardiomyocytes. Cell lines tested included several human embryonic stem cell lines, as well as iPS cell lines from numerous patients and various sources (including skin fibroblasts and cord blood cells). They also compared iPS cell lines made with traditional integrating factors as well as non-integrating episomal factors. Thus, it appears that this new protocol may allow for the generation of iPS cell lines from patients reliably and easily.

In addition to the good results, this protocol was both simple and cheap. Cells were differentiated in V-shaped 96-well plates, which was felt to result in uniform embryoid body formation. Then only a few factors, deemed to be critical for cardiogenesis, were used to induce differentiation, including bone morphogenetic protein 4 (BMP4), fibroblast growth factor 2 (FGF2), polyvinyl alcohol, serum, and insulin. Additionally, they found that hypoxia was only required to induce the iPS cell lines but not to induce the embryonic stem cell lines.

However, the work still has several limitations. First, enrichment is still not uniform and therefore not ideal. While $64 \%$ is good, the enrichment needs to be higher before the translational potential of this technology is realized. Second, it remains uncertain whether the cardiomyocytes generated in this study are mature or not. Immature or fetal myocytes have distinctly different biophysical properties. Accordingly, their creation would limit the utility of these myocytes for understanding and treating adult cardiac disease. Third, it remains to be determined whether this method can be successfully scaled up to generate the billions of cells needed for therapeutic use. As is, the 96-well-plate format poses a significant labor cost.

The promise of stem cells for the study and treatment of cardiovascular disease remains largely unfulfilled. And while the work performed by Burridge and colleagues may not provide much insight into the biological mechanisms of cardiac development, it represents a significant advancement in the field's technical ability to reliably produce cardiomyocytes from numerous cell lines, which is essential for realizing the full potential of induced cardiomyocytes.

\section{Abbreviations}

iPS, induced pluripotent stem; PS, pluripotent stem.

\section{Competing interests}

The authors declare that they have no competing interests.

\section{Authors' contributions}

EA and JKR both contributed to both the conceptualization as well as the composition of the work.

\section{Authors' information}

EA is an Associate Professor of Medicine at University of California, San Diego. JKR just completed her Master of Clinical Research and PhD at Oregon Health and Sciences University.

\section{Author details}

'Department of Molecular and Medical Genetics, Oregon Health and Science University, Portland, OR 97239, USA. ²Department of Medicine and Cardiology, University of California, San Diego, San Diego, CA 92037, USA.

Published: 15 August 2011

\section{References}

1. Yang L, Soonpaa MH, Adler ED, Roepke TK, Kattman SJ, Kennedy M, Henckaerts E, Bonham K, Abbott GW, Linden RM, Field L, Keller GM: Human cardiovascular progenitor cells develop from a KDR(+) embryonic-stemcell-derived population. Nature 2008, 453:524-528.

2. Carvajal-Vergara X, Sevilla A, D'Souza SL, Ang YS, Schaniel C, Lee DF, Yang L, Kaplan AD, Adler ED, Rozov R, Ge Y, Cohen N, Edelmann LJ, Chang B, Waghray A, Su J, Pardo S, Lichtenbelt KD, Tartaglia M, Gelb BD, Lemischka IR: Patientspecific induced pluripotent stem-cell-derived models of LEOPARD syndrome. Nature 2010, 465:808-812.

3. Moretti A, Bellin M, Welling A, Jung CB, Lam JT, Bott-Flugel L, Dorn T, Goedel A, Hohnke C, Hofmann F, Seyfarth M, Sinnecker D, Schomig A, Laugwitz KL: Patient-specific induced pluripotent stem-cell models for long-QT syndrome. N Engl J Med 2010, 363:1397-1409.

4. Adler ED, Chen VC, Bystrup A, Kaplan AD, Giovannone S, Briley-Saebo K, Young W, Kattman S, Mani V, Laflamme M, Zhu WZ, Fayad Z, Keller G: The cardiomyocyte lineage is critical for optimization of stem cell therapy in a mouse model of myocardial infarction. FASEB J 2010, 24:1073-1081.

5. Fernandes S, Naumova AV, Zhu WZ, Laflamme MA, Gold J, Murry CE: Human embryonic stem cell-derived cardiomyocytes engraft but do not alter cardiac remodeling after chronic infarction in rats. $J \mathrm{Mo} / \mathrm{Cell}$ Cardiol 2010, 49:941-949.

6. Caspi O, Huber I, Kehat I, Habib M, Arbel G, Gepstein A, Yankelson L, Aronson D, Beyar R, Gepstein L: Transplantation of human embryonic stem cellderived cardiomyocytes improves myocardial performance in infarcted rat hearts. J Am Coll Cardiol 2007, 50:1884-1893.

7. Yazawa M, Hsueh B, Jia X, Pasca AM, Bernstein JA, Hallmayer J, Dolmetsch RE: Using induced pluripotent stem cells to investigate cardiac phenotypes in Timothy syndrome. Nature 2011, 471:230-234.

8. Kattman SJ, Witty AD, Gagliardi M, Dubois NC, Niapour M, Hotta A, Ellis J, Keller G: Stage-specific optimization of activin/nodal and BMP signaling promotes cardiac differentiation of mouse and human pluripotent stem cell lines. Cell Stem Cell 2011, 8:228-240.

9. Laflamme MA, Chen KY, Naumova AV, Muskheli V, Fugate JA, Dupras SK, Reinecke H, Xu C, Hassanipour M, Police S, O'Sullivan C, Collins L, Chen Y, Minami E, Gill EA, Ueno S, Yuan C, Gold J, Murry CE: Cardiomyocytes derived from human embryonic stem cells in pro-survival factors enhance function of infarcted rat hearts. Nat Biotechno/ 2007, 25:1015-1024.

10. van Laake LW, Qian L, Cheng P, Huang Y, Hsiao EC, Conklin BR, Srivastava D: Reporter-based isolation of induced pluripotent stem cell- and embryonic stem cell-derived cardiac progenitors reveals limited gene expression variance. Circ Res 2010, 107:340-347.

11. Burridge PW, Thompson S, Millrod MA, Weinberg S, Yuan X, Peters A, Mahairaki V, Koliatsos VE, Tung L, Zambidis ET: A universal system for highly efficient cardiac differentiation of human induced pluripotent stem cells that eliminates interline variability. PLoS One 2011, 6:e18293.

doi:10.1186/scrt76

Cite this article as: Redig JK, Adler E: Doing the dirty work: progress in the search for a reliable protocol for cardiomyogenesis. Stem Cell Research \& Therapy 2011, 2:35. 